\title{
Information in the Tails of the Distribution of Analysts' Quarterly Earnings Forecasts
}

Cameron Truong

Phillip Shane

Qiuhong Zhao

Follow this and additional works at: https://scholarworks.wm.edu/businesspubs

\section{Recommended Citation}

Truong, C., Shane, P. B., \& Zhao, Q. (2016). Information in the tails of the distribution of analysts' quarterly earnings forecasts. Financial Analysts Journal, 72(5), 84-99.

This Article is brought to you for free and open access by the Mason School of Business at W\&M ScholarWorks. It has been accepted for inclusion in Mason School of Business Articles by an authorized administrator of W\&M ScholarWorks. For more information, please contact scholarworks@wm.edu. 


\title{
Information in the Tails of the Distribution of Analysts' Quarterly Earnings Forecasts
}

\author{
Cameron Truong, Philip B. Shane, and Qiuhong Zhao
}

\begin{abstract}
Investors generally measure earnings announcement news on the basis of the difference between actual earnings and two salient benchmarks: earnings in the same quarter the previous year and a consensus drawn from a distribution of forecasts by financial analysts. We evaluate the implications of a third salient benchmark: the most optimistic forecast when actual earnings exceed the consensus and the most pessimistic forecast when the consensus exceeds actual earnings. We find that considering the information in these tails of the distribution of analysts' earnings forecasts enhances the profitability of post-earnings announcement drift strategies.
\end{abstract}

I n our study, we investigated the stock price reaction to information in the tails of the distribution of financial analysts' quarterly earnings forecasts. As we know from the literature and the business press, the market's assessment of the news in a company's quarterly earnings announcement depends on the difference between actual earnings and two salient benchmarks: actual earnings in the same quarter the previous year and a consensus drawn from a distribution of analysts' forecasts leading up to the quarterly earnings announcement. In our study, we evaluated the implications of a third salient benchmark: the most optimistic forecast when actual earnings exceed the consensus and the most pessimistic forecast when the consensus exceeds actual earnings. We found that the market absorbs some but not all of the information in these tail forecasts; therefore, considering the information in the tails of the distribution of analysts' quarterly earnings forecasts enhances the profitability of momentum trading strategies that are based on quarterly earnings news. ${ }^{1}$

We refer to the most optimistic/pessimistic forecast as the tail forecast and to the difference between actual earnings and the tail forecast as the tail forecast error. We would expect the tail forecast error

Cameron Truong is associate professor of finance at Monash University, Melbourne, Australia. Philip B. Shane is the KPMG Professor and Chair of the Accounting Department at the Raymond A. Mason School of Business, College of William \& Mary, Williamsburg, Virginia. Qiuhong Zhao is assistant professor of accounting at the College of Business, Texas AEM University, Corpus Christi.

Editor's note: This article was reviewed and accepted by Robert Litterman, executive editor at the time the article was submitted. to contain incremental value-relevant information. Let us assume that actual earnings beat (miss) the consensus by a relatively large amount but that the most optimistic (pessimistic) forecast is much closer to or perhaps even above (below) actual earnings. In that case, the consensus and tail forecast errors present very different versions of earnings news, leading us to predict a somewhat muted market reaction to the traditional consensus-based measure of earnings news. Now consider the case in which actual earnings differ from the consensus forecast by a similarly large amount and the tail forecast is relatively close to the consensus. In this case, the consensus and tail forecast errors present largely consistent information, leading us to predict a stronger market reaction to the traditional consensus-based measure of earnings news. Moreover, in a market that incorporates information with a lag, we would expect a more pronounced post-earnings announcement drift (PEAD) in the case of relatively more consistent consensus and tail forecast errors.

Our empirical evidence suggests that the tails of the forecast distribution contribute economically and statistically significant information about the quality of the traditional measure of earnings surprise. $^{2}$ Using a sample of 126,205 company-quarters from the first quarter of 1987 to the second quarter of 2012, we found that companies with large tail forecast errors in the same direction as the consensus forecast errors experience significantly larger contemporaneous price reactions to consensus forecast errors and a significantly larger PEAD. We found similar results using tail forecast error in combination with unexpected earnings based on (1) a forecast from a quarterly seasonal random walk time-series model or (2) the stock price response around the earnings announcement. ${ }^{3}$ Consistent with Livnat 
and Mendenhall (2006) and Lerman, Livnat, and Mendenhall (2007), in our sample, a hedge portfolio with a long position in stocks in the top quintile of the distribution of forecast errors (based on expectations from both the seasonal random walk model and the consensus analyst forecast) and a short position in stocks with similarly derived bottom quintile quarterly forecast errors generates a $2.41 \%$ excess return in the next quarter. This hedge return increases to $4.43 \%$ when the long (short) positions are confined to stocks in the top (bottom) quintile of the tail forecast error distribution.

Because we based all portfolio rankings on cutoff values from the previous quarter, our results are free from look-ahead bias. Appendix A describes our robustness tests, showing that our results hold after controlling for various risk measures, proxies for information uncertainty, transaction costs, and other documented anomalies. ${ }^{4}$ As discussed in Appendix A, we observed higher abnormal trading volume after earnings announcements of companies experiencing larger tail forecast errors in the same direction as the consensus forecast errors. All the evidence points to the conclusion that tail forecast error captures substantial earnings information not captured by conventional measures of earnings surprise.

Our results are of interest to both researchers and practitioners. Researchers examining the contemporaneous/delayed market reaction to nonearnings information while controlling for the contemporaneous/delayed market reaction to earnings information should use all three proxies for unexpected earnings described in this article to avoid understating the market reaction to earnings news and overstating the market reaction to other information (see, e.g., Affleck-Graves and Mendenhall 1992; Bhushan 1994; Chan, Jegadeesh, and Lakonishok 1996; Collins and Hribar 2000; Bartov, Radhakrishnan, and Krinsky 2000; Mendenhall 2004; Francis, LaFond, Olsson, and Schipper 2004). Our study also contributes to the literature on analyst behavior and market efficiency in establishing that when tail forecasts deviate significantly from the consensus, one observes less underreaction to earnings news. For practitioners who aim to exploit PEAD, using all three measures of unexpected earnings helps generate significantly larger excess returns with a more concentrated trading portfolio. Our study provides strong empirical support for the practice of improving on consensus forecasts to seek investable opportunities. ${ }^{5}$ Finally, our findings offer further evidence that PEAD is probably due not to researcher error in measuring risk-adjusted returns but, rather, to economic or behavioral analyst/investor biases (see, e.g., Raedy, Shane, and Yang 2006; Cen, Hilary, and Wei 2013).

\section{Predictions}

Measures of earnings news generally require two inputs: a proxy for the market's definition of actual value-relevant earnings and a proxy for the best expectation of those earnings. Several studies have found evidence of both a contemporaneous and a delayed market reaction to earnings news, calculated as actual current-quarter earnings minus earnings for the same quarter of the previous year (e.g., Freeman and Tse 1989; Bernard and Thomas 1990; Chordia and Shivakumar 2006). Other studies have used a consensus measure of analyst earnings forecasts from Value Line or I/B/E/S to proxy for the market's expectation of actual value-relevant earnings (e.g., Abarbanell and Bernard 1992; Chan et al. 1996; Shane and Brous 2001; Bartov, Givoly, and Hayn 2002; Kasznik and McNichols 2002; Liang 2003; Mendenhall 2004; Ramnath, Rock, and Shane 2005). Traditional measures of expected earnings focus on measures of central tendency. In our study, we focused on incremental information in the tails of the distribution of analysts' forecasts, defining our scaled tail forecast-based unexpected earnings measure, SUETAIL, as follows:

$$
\begin{aligned}
\text { SUETAIL }_{i t}= & \left(E_{i t}-\mathrm{MAX}_{i t}\right) / P_{i t} \times(\mathrm{POST}) \\
& +\left(E_{i t}-\mathrm{MIN}_{i t}\right) / P_{i t} \times(1-\mathrm{POST}),
\end{aligned}
$$

where

$$
\begin{aligned}
\operatorname{MAX}_{i t}\left(\mathrm{MIN}_{i t}\right)= & \text { the maximum (minimum) } \\
& \mathrm{I} / \mathrm{B} / \mathrm{E} / \mathrm{S} \text { analyst forecast in } \\
& \text { the } 90 \text {-day period before the } \\
& \text { earnings announcement date } \\
\mathrm{POST}= & \text { a dummy that takes the value of } \\
& 1 \text { if the consensus forecast-based } \\
& \text { unexpected earnings }\left(E_{i t}-F_{i t}\right) \text { is } \\
& \text { greater than or equal to } 0 \text { and } \\
& \text { takes the value of } 0 \text { otherwise } \\
E_{i t}= & \text { quarterly earnings per I/B } / \mathrm{E} / \mathrm{S} \\
F_{i t}= & \text { the consensus analyst forecast }
\end{aligned}
$$

We scaled the numerator by the price per share for stock $i$ at the end of quarter $t$. Equation 1 is best illustrated with the following two examples.

Suppose that both Company A and Company B have equivalent positive forecast errors (computed by using a recent consensus of analysts' forecasts) but have different forecast errors computed by using the most optimistic forecast in the distribution from which the consensus forecast emerged. ${ }^{6}$

Although the two companies have the same consensus forecast errors ( 30 cents), the actual earnings of Company B beat the most optimistic forecast by 29 cents whereas the actual earnings of Company A beat the most optimistic forecast by only 5 cents. Thus, one analyst managed to predict actual earnings very well for Company A, and that analyst's clients might act on this superior prediction before the earnings announcement, leaving little room for 
Example 1.

\begin{tabular}{llll}
\hline Company A & & \multicolumn{2}{c}{ Company B } \\
\hline Earnings & 1.00 & Earnings & 1.00 \\
Consensus earnings forecast & $\underline{0.70}$ & Consensus earnings forecast & $\underline{0.70}$ \\
Consensus forecast error & $\underline{0.30}$ & Consensus forecast error & $\underline{0.30}$ \\
Earnings & 1.00 & Earnings & 1.00 \\
Most optimistic forecast & $\underline{0.95}$ & Most optimistic forecast & $\underline{0.71}$ \\
Tail forecast error & $\underline{\underline{0.05}}$ & Tail forecast error & $\underline{0.29}$ \\
\hline
\end{tabular}

\section{Example 2.}

\begin{tabular}{lrlr}
\hline Company A & & \multicolumn{2}{c}{ Company B } \\
\hline Earnings & 0.50 & Earnings & 0.50 \\
Consensus earnings forecast & $\underline{1.00}$ & Consensus earnings forecast & $\underline{1.00}$ \\
Consensus forecast error & $\underline{-0.50}$ & Consensus forecast error & $\underline{-0.50}$ \\
Earnings & 0.50 & Earnings & 0.50 \\
Most pessimistic forecast & $\underline{0.45}$ & Most pessimistic forecast & $\underline{0.95}$ \\
Tail forecast error & $\underline{+0.05}$ & Tail forecast error & $\underline{-0.45}$ \\
\hline
\end{tabular}

additional price movement concurrent with the earnings announcement. We hypothesize that the positive consensus-based forecast error for Company $\mathrm{B}$ conveys more positive earnings news than the consensus-based forecast error for Company A because, relative to Company A, Company B's earnings beat the most optimistic forecast in the distribution by a much larger amount.

Changing Example 1 slightly, let us assume that the most optimistic forecast for Company A is 1.05. The earnings forecast error based on the consensus (30 cents) would indicate a positive earnings surprise, whereas the earnings forecast error based on the most optimistic forecast ( -5 cents) would indicate a negative earnings surprise. Here, the market may be disappointed because actual earnings fall short of the most optimistic forecast even though actual earnings beat the consensus by a large margin. ${ }^{7}$

Now suppose that Company A and Company $B$ have equivalent negative earnings surprises (computed by using a recent consensus of analysts' forecasts) but have different forecast errors computed by using the most pessimistic forecast in the distribution from which the consensus forecast emerged.

Although the two companies have the same consensus forecast errors ( -50 cents), the actual earnings of Company B fall short of the most pessimistic forecast by 45 cents whereas the actual earnings of Company A exceed the most pessimistic forecast by 5 cents. Therefore, we conjecture that the negative surprise for Company B conveys more negative information than the negative surprise for Company A because, relative to Company A, Company B's earnings fall short of the most pessimistic forecast by a larger amount. In fact, relative to at least one extremely pessimistic forecast, Company B's earnings news is positive.

Under these examples, our first hypothesis predicts that the magnitude of the market reaction to earnings announcements characterized by positive (negative) consensus forecast errors increases with increases (decreases) in tail forecast errors that are measured with respect to the most optimistic (pessimistic) forecast in the distribution from which the consensus emerged.

Our second hypothesis evaluates PEAD as a function of earnings news. It predicts that the magnitude of the drift in stock prices following earnings announcements characterized by positive (negative) consensus forecast errors increases with increases (decreases) in tail forecast errors that are measured with respect to the most optimistic (pessimistic) forecast in the distribution from which the consensus emerged.

\section{Research Design}

We evaluated three measures of unexpected earnings in terms of their relationship with both the contemporaneous stock price reaction to earnings announcements and PEAD. Consistent with many prior studies, we obtained our first measure of unexpected earnings, SUE, from a rolling seasonal random walk model. Our second measure, SUECF, is based on the traditional measure of consensus analyst forecast error from I/B/E/S, whereby unexpected earnings equals actual quarterly earnings less the median forecast during a 90-day period leading up to the earnings announcement. Our third measure, SUETAIL, is defined as in Equation 1. We scaled all three measures by price as of the end of the fiscal quarter to which the earnings announcement refers. 
To mitigate effects of outliers and nonlinearities, we decile-ranked SUE, SUECF, and SUETAIL and transformed the decile ranks to fall along a scale between 0 and 1 . To eliminate any look-ahead bias, we used the ranking cutoffs from the previous quarter to assign stocks to one of 10 portfolios on the basis of SUE, SUECF, or SUETAIL in the current quarter, resulting in the rank variables DSUE, DSUECF, and DSUETAIL. The advantage of this method is that by regressing PEAD on these transformed variables, the coefficients on DSUE, DSUECF, and DSUETAIL can be interpreted as the return earned on an equally weighted portfolio that takes long positions in the top decile of the variable and short positions in the bottom decile of the variable.

Our primary motivation for SUETAIL was to provide information that supplements the information in SUECF or SUE such that the market reaction and PEAD associated with the interaction of SUECF and SUETAIL or the interaction of SUE and SUETAIL are stronger than the market reaction and PEAD associated with SUECF or SUE alone. Although our results confirm this prediction, we also found that a hedge portfolio trading strategy based on SUETAIL alone produces significant positive abnormal returns.

To examine the role of each surprise measure in relation to the contemporaneous market reaction to the news in an earnings announcement and PEAD, we estimated the following models:

$$
\begin{aligned}
& \mathrm{CAR}_{i, q}=\text { Intercept }+a_{1} \times \mathrm{DSUE}_{i, q}+a_{2} \\
& \times \text { DSUECF }_{i, q}+a_{3} \times \text { DSUETAIL }_{i, q} \\
& +u \\
& \mathrm{PEAD}_{i, q}=\text { Intercept }+a_{1} \times \mathrm{DSUE}_{i, q}+a_{2} \\
& \times \operatorname{DSUECF}_{i, q}+a_{3} \times \operatorname{DSUETAIL}_{i, q}(3 \\
& +u
\end{aligned}
$$

CAR is a three-day buy-and-hold excess return surrounding each earnings announcement, and PEAD is a buy-and-hold excess return from day +2 following the earnings announcement through the day following the next quarter's earnings announcement or through the day +100 when the date of the next quarterly earnings announcement is missing (Berkman and Truong 2009). Buy-and-hold excess return is computed as the difference between raw return and the return on a portfolio of companies matched on size and book-to-market value.

To implement our tests of the hypotheses that SUETAIL adds value in explaining both the contemporaneous market reaction to the news in an earnings announcement and the drift in returns following the earnings announcement, we estimated the following models:

$$
\begin{aligned}
& \mathrm{CAR}_{i, q}=\text { Intercept }+a_{1} \times \mathrm{DSUE}_{i, q}+a_{2} \\
& \times \operatorname{DSUE}_{i, q} \times \operatorname{DSUETAIL}_{i, q}+u \\
& \mathrm{CAR}_{i, q}=\text { Intercept }+a_{1} \times \mathrm{DSUECF}_{i, q}+a_{2} \\
& \times \text { DSUECF }_{i, q} \times \text { DSUETAIL }_{i, q}+u \\
& \mathrm{PEAD}_{i, q}=\text { Intercept }+a_{1} \times \mathrm{DSUE}_{i, q}+a_{2} \\
& \times \operatorname{DSUE}_{i, q} \times \text { DSUETAIL }_{i, q}+u \\
& \operatorname{PEAD}_{i, q}=\text { Intercept }+a_{1} \times \mathrm{DSUECF}_{i, q}+a_{2} \\
& \times \operatorname{DSUECF}_{i, q} \times \text { DSUETAIL }_{i, q}+u
\end{aligned}
$$

We report our results from the regressions we conducted, with standard errors of coefficients clustered by company and quarter (Petersen 2009; Gar, Ormazabal, and Taylor 2010; Thompson 2011).

\section{Results}

We report and discuss our results with respect to descriptive statistics, contemporaneous market responses to earnings surprises, and market efficiency regarding the three earnings news proxies.

Descriptive Statistics. Table 1 outlines the derivation of our sample and provides descriptive statistics for variables included in our tests of hypotheses. Panel A shows that we began with all 1,649,763 company-quarters available from I/B/E/S from the first quarter of 1987 to the second quarter of 2012. We then applied screens to reduce the number of observations to those with the data needed to test our hypotheses. First, we eliminated observations without Compustat data needed to calculate SUE $(473,058$ observations). Second, we excluded observations without earnings announcement dates on Compustat (224,089 observations). Third, we reduced measurement error by eliminating observations with earnings announcement dates (per Compustat) that were not within at least one day of the earnings announcement dates available from I/B/E/S (146,181 observations). Fourth, we eliminated observations without the necessary price deflator from Compustat or with a price deflator less than $\$ 1$ (40,944 observations). Fifth, we excluded observations with missing book or market values of equity or with book or market values less than $\$ 5$ million (75,959 observations). Finally, we eliminated observations for which we could not obtain the CRSP data needed to measure CAR and PEAD (516,128 observations) and observations concerning companies without the cutoffs of SUE, SUECF, and SUETAIL from the previous quarter $(47,199)$. These screens left us with 126,205 observations to include in the tests of our hypotheses. ${ }^{8}$

Panel B of Table 1 provides summary statistics of the variables in the main tests of our hypotheses plus the variable STD, which measures the dispersion in 
Table 1. Sample Selection and Descriptive Statistics

\section{A. Sample selection}

All I/B/E/S company-quarters with consensus forecasts from Q1:1987 to Q2:2012

$1,649,763$

Exclude observations without Compustat quarterly data to compute SUE

Subtotal after merging with Compustat data

$1,176,705$

Exclude observations without earnings announcement dates reported in Compustat

Exclude observations where earnings announcement dates in Compustat and I/B/E/S differ by more than one calendar day

Exclude observations where the price per share from Compustat at fiscal quarter-end is missing or less than $\$ 1$

Exclude observations with market (or book) equity missing or less than $\$ 5$ million

Subtotal: Number of company-quarters before merging with CRSP

Exclude company-quarters without matching CRSP data needed to compute CAR and PEAD

Subtotal: Number of company-quarters after merging with CRSP data

173,404

Exclude company-quarters without cutoffs of SUE, SUECF, and SUETAIL from the previous quarter

\begin{tabular}{|c|c|c|c|c|c|c|c|c|}
\hline \multirow[b]{2}{*}{ Variable } & \multirow[b]{2}{*}{$N$} & \multirow[b]{2}{*}{ Mean } & \multirow[b]{2}{*}{ Std. Dev. } & \multicolumn{5}{|c|}{ Percentile } \\
\hline & & & & 10th & 25th & 50 th & 75th & 90th \\
\hline \multicolumn{9}{|c|}{ B. Summary statistics of key variables } \\
\hline SUE & 126,205 & -0.0011 & 0.2682 & -0.0222 & -0.0045 & 0.0015 & 0.0055 & 0.0170 \\
\hline SUECF & 126,205 & -0.0013 & 0.0648 & -0.0039 & -0.0004 & 0.0004 & 0.0017 & 0.0046 \\
\hline SUETAIL & 126,205 & -0.0017 & 0.0640 & -0.0038 & -0.0009 & 0.0000 & 0.0010 & 0.0033 \\
\hline CAR & 126,205 & 0.0026 & 0.0809 & -0.0799 & -0.0324 & 0.0014 & 0.0375 & 0.0868 \\
\hline PEAD & 126,205 & 0.0027 & 0.2158 & -0.2201 & -0.1025 & -0.0044 & 0.0934 & 0.2143 \\
\hline $\mathrm{MV}_{(t-1)}$ & 126,205 & $6,348.91$ & $0,923.63$ & 182.49 & 450.67 & $1,295.13$ & $4,018.69$ & $12,840.20$ \\
\hline Price & 126,205 & 31.1932 & 29.1912 & 7.8750 & 14.7500 & 25.8500 & 40.4000 & 57.9999 \\
\hline \multirow[t]{2}{*}{ STD } & 126,205 & 0.0477 & 0.2204 & 0.0057 & 0.0100 & 0.0212 & 0.0471 & 0.0968 \\
\hline & SUE & SUECF & SUETAIL & CAR & PEAD & $\mathrm{MV}_{(t-1)}$ & Price & STD \\
\hline \multicolumn{9}{|c|}{ C. Spearman correlations among key variables } \\
\hline \multirow[t]{2}{*}{ SUE } & 1.0000 & 0.2986 & 0.2202 & 0.1266 & 0.0289 & 0.0393 & 0.1061 & -0.0660 \\
\hline & & $<0.0001$ & $<0.0001$ & $<0.0001$ & $<0.0001$ & $<0.0001$ & $<0.0001$ & $<0.0001$ \\
\hline \multirow[t]{2}{*}{ SUECF } & & 1.0000 & 0.4317 & 0.2978 & 0.0444 & 0.0113 & 0.0119 & -0.0025 \\
\hline & & & $<0.0001$ & $<0.0001$ & $<0.0001$ & $<0.0001$ & $<0.0001$ & 0.3774 \\
\hline \multirow[t]{2}{*}{ SUETAIL } & & & 1.0000 & 0.1969 & 0.0322 & -0.0188 & 0.0358 & -0.0926 \\
\hline & & & & $<0.0001$ & $<0.0001$ & $<0.0001$ & $<0.0001$ & $<0.0001$ \\
\hline \multirow[t]{2}{*}{ CAR } & & & & 1.0000 & 0.0386 & 0.0072 & 0.0233 & -0.0196 \\
\hline & & & & & $<0.0001$ & 0.0103 & $<0.0001$ & $<0.0001$ \\
\hline \multirow[t]{2}{*}{ PEAD } & & & & & 1.0000 & 0.0393 & 0.0238 & 0.0038 \\
\hline & & & & & & $<0.0001$ & $<0.0001$ & 0.1720 \\
\hline \multirow[t]{2}{*}{$\mathrm{MV}_{(t-1)}$} & & & & & & 1.0000 & 0.6367 & 0.1126 \\
\hline & & & & & & & $<0.0001$ & $<0.0001$ \\
\hline \multirow[t]{2}{*}{ Price } & & & & & & & 1.0000 & 0.1373 \\
\hline & & & & & & & & $<0.0001$ \\
\hline STD & & & & & & & & 1.0000 \\
\hline
\end{tabular}

the distribution of forecasts from which we derived the median and tail forecasts for purposes of measuring SUECF and SUETAIL, respectively. Our primary test variables-SUE, SUECF, SUETAIL, CAR, and PEAD—have reasonably symmetrical distributions around zero and substantial variability, because the standard deviation of each distribution is large relative to the mean of each distribution. The mean and median market values of equity are $\$ 6.35$ billion and $\$ 1.30$ billion, respectively. The mean and median market values of the price deflator are $\$ 31.19$ and $\$ 25.85$, and the mean and median values of the measure of forecast dispersion (STD) are 0.0477 and 0.0212 . Thus, the distributions of the market values of equity, price, and forecasts are all skewed to the right, consistent with the literature. 
Panel $C$ of Table 1 shows that our three proxies for unexpected earnings (SUE, SUETAIL, and SUECF) are significantly but by no means perfectly correlated, leaving plenty of room for each to provide incremental information about the company's earnings news. Panel $C$ also shows that each measure of earnings surprise is significantly correlated with both contemporaneous and future returns, providing evidence of contemporaneous market reactions to earnings news and PEAD in our sample. SUECF has the highest correlation with both CAR $(-1,1)$ and PEAD, our new earnings surprise proxy (SUETAIL) is second in both categories, and SUE is third. As expected, STD (our measure of forecast dispersion) and SUETAIL are negatively correlated, making STD an important control variable in our robustness tests. The Spearman correlation is about $-9.26 \%$, which is highly significant but far from perfect. ${ }^{9}$
Contemporaneous Market Response to Earnings Surprise. We report our results from regressing CAR $(-1,1)$ against three measures of earnings surprise. As shown in Panel A of Table 2, threeday excess returns corresponding to the top decile of earnings surprise exceed similarly computed returns related to the bottom decile of earnings surprise by $7.17 \%$ if surprise is measured by DSUECF, $4.79 \%$ if measured by DSUETAIL, and $2.96 \%$ if measured by DSUE. The two-way-clustered $t$-statistics of the coefficients on the three measures are all highly significant.

As shown in the far-right column of Panel A (model 2), all three earnings news proxies help explain the variation in returns during the three-day window centered on the earnings announcement. Although DSUECF seems the best proxy, the other two measures contain information about the market's earnings

Table 2. Regressions of CAR $(-1,1)$ on DSUE, DSUECF, and DSUETAIL (t-statistics in parentheses)

\begin{tabular}{lcccc}
\hline Variable & DSUECF & DSUETAIL & DSUE & DSUE, DSUECF, and \\
DSUETAIL (Model 2)
\end{tabular}


surprise that DSUECF does not. There is a hierarchy regarding the power to explain contemporaneous market reaction: DSUECF is the strongest (coefficient $=0.0605 ;$ - -statistic $=25.85$ ), followed by DSUETAIL (coefficient $=0.0220 ;$ - -statistic $=21.80$ ) and then DSUE (coefficient $=0.0066 ; t$-statistic $=5.60)$.

Panel B of Table 2 shows the results of estimating models 4 and 5-testing the hypothesis that the contemporaneous market reaction to an earnings announcement increases with the magnitude of the interaction between (1) DSUE and our new measure of earnings surprise, DSUETAIL, and (2) DSUECF and DSUETAIL. As shown in Panel B, the interaction terms, DSUE $\times$ DSUETAIL and DSUECF $\times$ DSUETAIL, are highly significant, suggesting that the contemporaneous market response to consensus analyst forecast errors or to time-series model forecast errors increases with the degree to which the most optimistic/pessimistic forecast conforms to the consensus. This result supports our first prediction.

Market Efficiency regarding Three Earnings News Proxies. Table 3 reports the results of regressing the PEAD against four measures of earnings surprise. Brandt, Kishore, Santa-Clara, and Venkatachalam (2008) and Zhou and Zhu (2012) documented that a trading strategy based on long (short) positions in the top (bottom) quintile of stocks sorted on abnormal earnings announcement returns (EAR) earns significant abnormal returns in the postearnings announcement period. ${ }^{10}$ We thus included EAR as the fourth earnings surprise measure, regarding the stock price response in the three-day window surrounding the earnings announcement.

Coefficients on the earnings surprise proxies provide estimates of gains to a trading strategy taking long (short) positions in stocks in the top (bottom) decile of the earnings surprise proxy distribution. From day +2 following the earnings announcement through the day following the next quarter's earnings announcement-or day +100 when the date of the next quarterly earnings announcement is missingthe trading strategy produces an estimated $2.69 \%$ return when surprise is measured by SUECF, $1.67 \%$ when measured by SUETAIL, $1.30 \%$ when measured by SUE, and $2.34 \%$ when measured by EAR. Model 3 in Panel A of Table 3 shows that DSUECF and DSUETAIL contribute statistically significant power in explaining the drift in returns following the earnings announcement. The regression coefficients suggest that one could earn an approximately $3.41 \%$ quarterly return on a strategy that takes long positions in stocks in the highest decile of all three measures of earnings surprise and a short position in the lowest decile of those measures. Our DSUETAIL measure contributes a unique $0.65 \%$ abnormal hedge portfolio return, which is $19 \%$ of the estimated total hedge portfolio return. For further comparisons, the far-right column of Panel A shows that when all four earnings surprise measures are included, DSUETAIL retains its important contribution to the abnormal hedge portfolio return.

Model 7 in Panel B of Table 3 shows that when PEAD is regressed on DSUECF and the interaction of DSUECF and DSUETAIL, we obtain a $1.73 \%$ abnormal return to a trading strategy based on long (short) positions in stocks in the top (bottom) decile of SUECF alone, which increases significantly to 3\% $(=1.73 \%+$ $1.27 \%$ ) when the strategy is confined to stocks also in the top (bottom) decile of the SUETAIL distribution. The coefficient on the interaction term is highly significant, with a $t$-statistic of 2.58 ( $p$-value $<0.01)$. This result confirms our second hypothesis, which predicts that the amount of PEAD increases significantly with the interaction of DSUECF (the traditional measure of earnings surprise) and DSUETAIL (our new measure based on tail forecasts in the distribution from which the consensus emerges). Model 6 in Panel B confirms similar interactive power between DSUE and DSUETAIL. The spread between companies in the top SUE decile and companies in the bottom SUE decile increases from $-0.34 \%$ to $2.31 \%$ when the trading strategy is confined to companies also in the top and bottom SUETAIL deciles. The interaction term is highly significant, with a $t$-statistic of 5.53. The model in the far-right column of Panel B shows that when DEAR interacts with DSUETAIL, the spread between companies in the top EAR decile and companies in the bottom EAR decile increases from $0.86 \%$ to $3.28 \%$. Again, the interaction term is highly significant, with a $t$-statistic of 5.18, providing further evidence of the importance of DSUETAIL in assessing PEAD.

Table 4 reports our analysis of hedge portfolio PEAD returns in relation to different combinations of the three primary earnings news proxies. Panel A shows our analysis of PEAD for various combinations of the DSUECF and DSUETAIL variables. We obtain statistically significant hedge portfolio quarterly returns of $1.51 \%, 2.03 \%$, and $2.17 \%$ with long (short) positions in stocks in the top (bottom) quintile of the distribution of SUECF while holding SUETAIL constant. Thus, the average return to a SUECF-based trading strategy that holds SUETAIL constant is only $1.90 \%$, compared with $3.39 \%$ for a trading strategy that takes long (short) positions in stocks whose SUE and SUETAIL are in the top (bottom) quintile of their respective distribution. ${ }^{11}$

Panel B of Table 4 shows hedge portfolio quarterly returns of $0.78 \%, 0.65 \%$, and $2.13 \%$ for long (short) positions in the top (bottom) quintile of the distribution of SUE, with SUETAIL held constant. Thus, the average return to a SUE-based trading strategy that holds SUETAIL constant is only $1.19 \%$, compared with 
Table 3. Regressions of PEAD on DSUE, DSUECF, DSUETAIL, and DEAR

( $t$-statistics in parentheses)

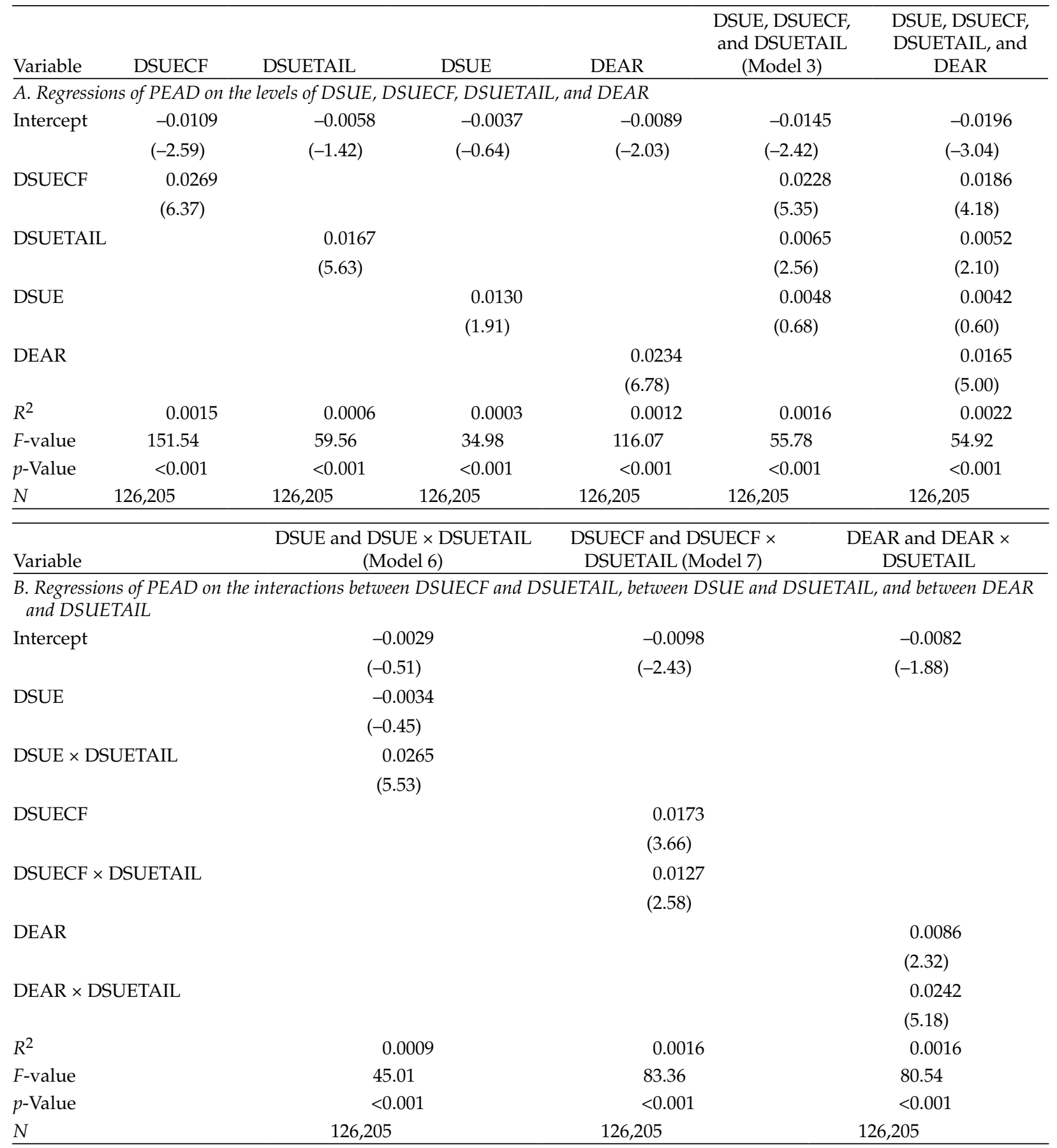

$3.22 \%$ for a trading strategy that takes long (short) positions in stocks whose SUE and SUETAIL are in the top (bottom) quintile of their respective distribution.

Livnat and Mendenhall (2006) and Lerman et al. (2007) suggested that using SUECF and SUE simultaneously results in the highest PEAD hedge return. Following this suggestion, we restricted the sample in Panel C of Table 4 to observations whose quintile rankings of SUECF and SUE agree and assessed the incremental effect of considering the quintile rank of SUETAIL. Holding SUETAIL constant, we found significant returns to a trading strategy that takes long (short) positions in stocks whose SUECF and SUE are both in the top (bottom) quintile of their respective distribution. These quarterly returns are $1.38 \%$, $2.36 \%$, and $3.49 \%$, respectively, when SUETAIL is in the bottom, middle, and top quintiles of its distribution. Thus, the average return to a trading strategy based simultaneously on SUECF and SUE that holds SUETAIL constant is $2.41 \%$. The hedge return jumps 
Table 4. Post-Earnings Announcement Drift Based on DSUECF, DSUE, and DSUETAIL ( $t$-statistics in parentheses)

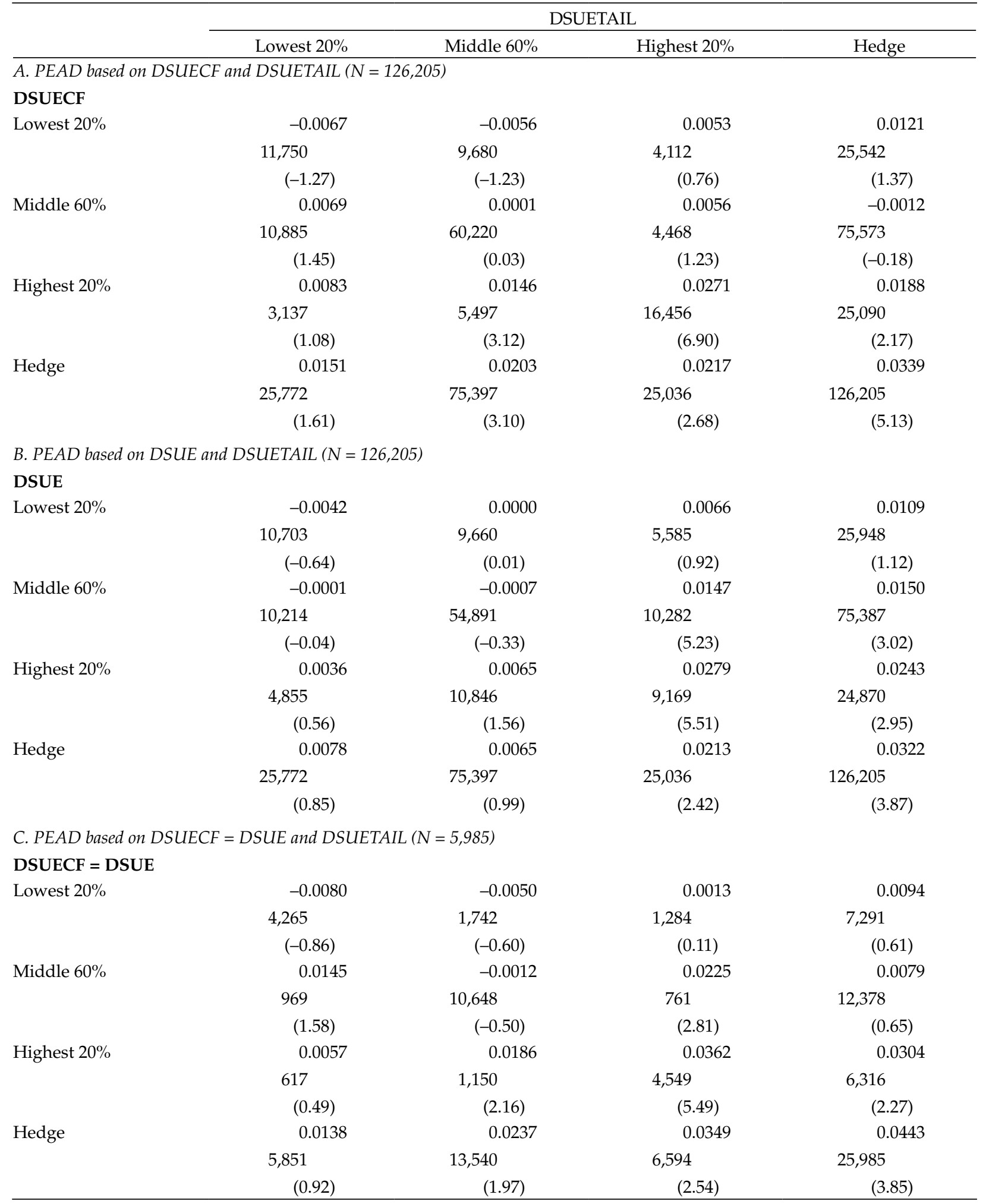


to $4.43 \%$ with a trading strategy that takes long (short) positions in stocks whose three earnings surprise measures are in their respective top (bottom) quintile.

Taken as a whole, the evidence in Table 4 strongly suggests that tail forecast errors contain valuerelevant information to which the market incrementally underreacts, as indicated by the delayed returns associated with SUETAIL in combination with the two conventional measures of earnings surpriseSUE and SUECF. ${ }^{12}$

\section{Conclusion}

Quarter after quarter, earnings announcements consistently rank among the most newsworthy information events affecting the value of companies' securities. Effective proxies for earnings surprise are important for at least two reasons. First, we have no theory to guide measurement of the news the market derives from an earnings announcement. Second, the search for a proxy for earnings news that the market fails to fully absorb leads to trading profits and, as those trading profits are arbitraged away, to stock prices that more efficiently absorb accounting information and allocate resources in capital markets.

Our study contributes a new measure of earnings surprise that affords greater understanding of the process by which the market forms earnings expectations. Our measure of earnings surprise complements the news derived from two conventional measures: one based on consensus analyst forecasts and the other based on predictions from a seasonal random walk time-series model. We found that when the most optimistic/pessimistic forecast in the distribution of forecasts composing the consensus is closer to the conventionally measured forecast, the market views the conventionally measured earnings news as more persistent, reacting more strongly in the three-day window surrounding the earnings announcement but also underreacting to this incremental information as reflected by significantly more PEAD.

Consequently, we found evidence of larger hedge portfolio returns to trading strategies based on long (short) positions in the top (bottom) deciles and quintiles of conventionally measured earnings surprise when these decile and quintile assignments are similar to those based on our new measure of earnings surprise. Appendix A shows that trading volume around the time of the earnings announcement supplies corroborating evidence that our new measure of earnings surprise provides heretofore uncovered value-relevant information in earnings announcements and in the tails of the distribution of analysts' earnings forecasts leading up to quarterly earnings announcements.
Moreover, we found that tail forecast error contributes unique information explaining both the market's contemporaneous reaction to earnings news and the drift in returns after the earnings announcement. Our results have implications for researchers seeking a better understanding of how the market forms its earnings expectations, for investors seeking higher returns from trading on the news in earnings announcements, and for financial analysts seeking to improve their earningsbased research and recommendations. Overall, this study improves our understanding of the process by which accounting information affects market prices.

We appreciate helpful comments from Henk Berkman, Charles Corrado, David Emanuel, Nam Tran, and seminar participants at the University of Auckland, Deakin University, Louisiana State University, Monash University, and the 2009 Annual Meetings and 2010 Western Region Meetings of the American Accounting Association. Philip Shane gratefully acknowledges financial support from the Frank Wood Accounting Faculty Research Fund at the Raymond A. Mason School of Business, College of William \& Mary.

$$
\begin{aligned}
& \text { CE Qualified } \\
& \text { Activity } \\
& \text { 亚 CFA Institute } 1 \text { CE credit }
\end{aligned}
$$

\section{Appendix A. Additional Analyses and Robustness Tests}

In this appendix, we report additional analyses and robustness test results regarding control variables, abnormal trading volume around earnings announcements, and transaction costs, as well as other untabled robustness tests.

\section{Control Variables}

The PEAD-SUE and PEAD-SUECF relationships have been shown to be sensitive to arbitrage risk (Mendenhall 2004), abnormal trading volume (Bhushan 1994; Garfinkel and Sokobin 2006), revenue surprise (Jegadeesh and Livnat 2006), and dispersion of analysts' forecasts (Dische 2002; Liang 2003; Garfinkel and Sokobin 2006). Table A1 shows that the delayed market reaction to the incremental information in SUETAIL remains significant after the inclusion of these variables as well as risk factors that might limit arbitrage trading.

As shown in Table A1, after adding these variables and allowing them to interact with DSUE and DSUECF in the same manner as our variable of interest, DSUETAIL, the coefficient on DSUE alone becomes insignificant but the coefficient on the interaction of DSUETAIL and both DSUE (Panel A) and 
Table A1. Determinants of Post-Earnings Announcement Drift

( $t$-statistics in parentheses)

\begin{tabular}{|c|c|c|c|c|c|c|c|c|}
\hline Variable & DSUETAIL & DREV & DARB & DEXP & DSTD & $\mathrm{DP}$ & DVOL & Full Model \\
\hline \multicolumn{9}{|c|}{ A. Regressions of PEAD on DSUE and interaction of DSUE and DSUETAIL } \\
\hline \multirow[t]{2}{*}{ Intercept } & 0.0010 & 0.0003 & 0.0008 & 0.0004 & 0.0006 & 0.0007 & 0.0004 & 0.0023 \\
\hline & $(0.16)$ & $(0.05)$ & $(0.12)$ & $(0.06)$ & $(0.10)$ & $(0.11)$ & $(0.06)$ & $(0.34)$ \\
\hline \multirow[t]{2}{*}{ DSUE } & -0.0033 & 0.0090 & 0.0039 & 0.0124 & 0.0059 & 0.0160 & 0.0081 & -0.0165 \\
\hline & $(-0.39)$ & $(1.10)$ & $(0.27)$ & $(1.23)$ & $(0.62)$ & $(2.26)$ & $(0.81)$ & $(-0.63)$ \\
\hline \multirow[t]{2}{*}{ DSUE $\times$ DSUETAIL } & 0.0226 & & & & & & & 0.0242 \\
\hline & $(4.47)$ & & & & & & & $(4.45)$ \\
\hline \multirow[t]{2}{*}{ DSUE $\times$ DREV } & & 0.0032 & & & & & & 0.0130 \\
\hline & & $(0.35)$ & & & & & & $(0.75)$ \\
\hline \multirow[t]{2}{*}{ DSUE $\times$ DARB } & & & 0.0114 & & & & & 0.0097 \\
\hline & & & $(0.64)$ & & & & & $(0.49)$ \\
\hline \multirow[t]{2}{*}{ DSUE $\times$ DEXP } & & & & -0.0035 & & & & -0.0022 \\
\hline & & & & $(-0.36)$ & & & & $(-0.18)$ \\
\hline \multirow[t]{2}{*}{ DSUE $\times$ DSTD } & & & & & 0.0086 & & & 0.0118 \\
\hline & & & & & $(1.49)$ & & & $(1.70)$ \\
\hline \multirow[t]{2}{*}{$\mathrm{DSUE} \times \mathrm{DP}$} & & & & & & -0.0117 & & -0.0153 \\
\hline & & & & & & $(-1.03)$ & & $(-0.94)$ \\
\hline \multirow[t]{2}{*}{ DSUE $\times$ DVOL } & & & & & & & 0.0049 & 0.0027 \\
\hline & & & & & & & $(0.49)$ & $(0.17)$ \\
\hline$N$ & 94,479 & 94,479 & 94,479 & 94,479 & 94,479 & 94,479 & 94,479 & 94,479 \\
\hline \multicolumn{9}{|c|}{ B. Regressions of PEAD on DSUECF and interaction of DSUECF and DSUETAIL } \\
\hline \multirow[t]{2}{*}{ Intercept } & -0.0052 & -0.0060 & -0.0052 & -0.0060 & -0.0060 & -0.0050 & -0.0061 & -0.0033 \\
\hline & $(-1.22)$ & $(-1.35)$ & $(-1.11)$ & $(-1.39)$ & $(-1.34)$ & $(-1.02)$ & $(-1.39)$ & $(-0.63)$ \\
\hline \multirow[t]{2}{*}{ DSUECF } & 0.0157 & 0.0228 & 0.0112 & 0.0219 & 0.0235 & 0.0313 & 0.0188 & -0.0033 \\
\hline & $(3.20)$ & (3.36) & (1.12) & $(2.63)$ & $(3.98)$ & $(4.90)$ & $(3.50)$ & $(-0.15)$ \\
\hline \multirow[t]{2}{*}{ DSUECF $\times$ DSUETAIL } & 0.0097 & & & & & & & 0.0127 \\
\hline & $(1.93)$ & & & & & & & $(2.45)$ \\
\hline \multirow[t]{2}{*}{ DSUECF $\times$ DREV } & & 0.0002 & & & & & & 0.0150 \\
\hline & & $(0.02)$ & & & & & & $(0.87)$ \\
\hline \multirow[t]{2}{*}{ DSUECF $\times$ DARB } & & & 0.0198 & & & & & 0.0178 \\
\hline & & & $(1.13)$ & & & & & $(0.96)$ \\
\hline \multirow[t]{2}{*}{ DSUECF $\times$ DEXP } & & & & 0.0022 & & & & 0.0046 \\
\hline & & & & $(0.16)$ & & & & $(0.29)$ \\
\hline \multirow[t]{2}{*}{ DSUECF $\times$ DSTD } & & & & & -0.0009 & & & 0.0057 \\
\hline & & & & & $(-0.15)$ & & & $(0.77)$ \\
\hline \multirow[t]{2}{*}{ DSUECF $\times$ DP } & & & & & & -0.0206 & & -0.0214 \\
\hline & & & & & & $(-1.44)$ & & $(-1.12)$ \\
\hline \multirow[t]{2}{*}{ DSUECF $\times$ DVOL } & & & & & & & 0.0086 & 0.0043 \\
\hline & & & & & & & $(0.92)$ & $(0.28)$ \\
\hline$N$ & 94,479 & 94,479 & 94,479 & 94,479 & 94,479 & 94,479 & 94,479 & 94,479 \\
\hline
\end{tabular}

DSUECF (Panel B) is virtually unaffected and remains significant. $^{13}$

\section{Abnormal Trading Volume around Earnings Announcements}

In addition to stock price changes, prior literature has analyzed trading volume as a measure of the market's response to information events, including earnings announcements. Table A2 examines whether abnormal trading in the earnings announcement window is related to earnings information captured by SUETAIL. Table A2 shows that trading volume is high (low) when the information in SUETAIL corroborates (contradicts) the information in the SUE and SUECF signals. 
Table A2. Abnormal Trading Volume around Earnings Announcement Date Based on DSUECF, DSUE, and DSUETAIL

( $t$-statistics in parentheses)

\begin{tabular}{|c|c|c|c|c|}
\hline & \multicolumn{4}{|c|}{ DSUETAIL } \\
\hline & Lowest $20 \%$ & Middle $60 \%$ & Highest $20 \%$ & Highest $20 \%$ - Lowest $20 \%$ \\
\hline \multicolumn{5}{|c|}{ A. Abnormal trading volume based on DSUECF and DSUETAIL $(N=126,205)$} \\
\hline \multicolumn{5}{|l|}{ DSUECF } \\
\hline \multirow[t]{2}{*}{ Lowest $20 \%$} & 1.2838 & 0.8805 & 0.6471 & -0.6367 \\
\hline & $(22.13)$ & $(22.44)$ & $(16.67)$ & $(-9.10)$ \\
\hline \multirow[t]{2}{*}{ Middle $60 \%$} & 0.5785 & 0.7126 & 0.7121 & 0.1335 \\
\hline & $(18.61)$ & $(28.83)$ & $(20.84)$ & $(2.89)$ \\
\hline \multirow[t]{2}{*}{ Highest $20 \%$} & 0.5834 & 0.7737 & 0.9187 & 0.3353 \\
\hline & $(17.76)$ & $(13.80)$ & $(28.27)$ & $(7.26)$ \\
\hline \multicolumn{5}{|c|}{ B. Abnormal trading volume based on DSUE and DSUETAIL $(N=126,205)$} \\
\hline \multicolumn{5}{|l|}{ DSUE } \\
\hline \multirow[t]{2}{*}{ Lowest $20 \%$} & 0.9817 & 0.6930 & 0.7153 & -0.2664 \\
\hline & $(23.78)$ & (22.93) & $(15.82)$ & $(-4.35)$ \\
\hline \multirow[t]{2}{*}{ Middle $60 \%$} & 0.8495 & 0.7420 & 0.7916 & -0.0579 \\
\hline & $(19.43)$ & $(28.84)$ & $(24.31)$ & $(-1.06)$ \\
\hline \multirow[t]{2}{*}{ Highest $20 \%$} & 0.7677 & 0.7959 & 0.9659 & 0.1982 \\
\hline & $(19.73)$ & $(25.68)$ & $(24.24)$ & $(3.56)$ \\
\hline \multicolumn{5}{|c|}{ C. Abnormal trading volume based on DSUECF = DSUE and DSUETAIL $(N=25,985)$} \\
\hline \multicolumn{5}{|c|}{ DSUECF $=$ DSUE } \\
\hline \multirow[t]{2}{*}{ Lowest $20 \%$} & 1.3382 & 0.7154 & 0.6509 & -0.6873 \\
\hline & $(16.41)$ & (15.29) & (11.03) & $(-6.81)$ \\
\hline \multirow[t]{2}{*}{ Middle $60 \%$} & 0.6363 & 0.6997 & 0.6960 & 0.0597 \\
\hline & $(7.82)$ & $(23.87)$ & (12.17) & $(0.60)$ \\
\hline \multirow[t]{2}{*}{ Highest $20 \%$} & 0.5909 & 0.7414 & 1.0047 & 0.4138 \\
\hline & $(9.31)$ & (15.75) & (22.16) & $(5.34)$ \\
\hline
\end{tabular}

\section{Transaction Costs}

Table A3 reports the implications of transaction costs for trading on the PEAD. In Panel A, companies in the bottom $20 \%$ of both SUECF and SUETAIL have an average market capitalization of $\$ 2.06$ billion, whereas companies in the top $20 \%$ of both SUECF and SUETAIL have an average market capitalization of $\$ 2.78$ billion. In Panel B, companies in the bottom $20 \%$ of both SUE and SUETAIL have an average market capitalization of $\$ 2.43$ billion, whereas companies in the top $20 \%$ of both SUE and SUETAIL have an average market capitalization of $\$ 2.76$ billion. In Panel C, companies in the bottom $20 \%$ of all three earnings surprise measures have an average market capitalization of about $\$ 1.27$ billion. Companies in the top $20 \%$ of all three earnings surprise measures have an average market capitalization of about $\$ 2.46$ billion. Given that the average market capitalization of the overall sample is $\$ 6.3$ billion (Table 1 ), smaller stocks tend to occupy the trading portfolios, but these stocks are not so small as to suggest insurmountable liquidity constraints. Average turnover, measured as trading volume on day +2 relative to total shares outstanding, is generally more than $1 \%$ across all three panels, which also suggests adequate liquidity for trading these companies.

To account for transaction costs and to elicit investable returns, Table A3 also examines PEAD returns after accounting for transaction costs. Following Chung and Zhang (2014), we used daily closing bid and ask prices to compute the daily quoted spread for each stock, and following Battalio and Mendenhall (2011), we assumed that investors pay half of the stock's quoted bid-ask spread when initiating their positions (on day +2 ) and again pay half the quoted bid-ask spread when terminating the positions. After accounting for transaction costs, the hedge returns are 2.09\% in Panel A and 2.05\% in Panel B. These returns are significant at the $1 \%$ level and are economically large. In Panel C, the hedge return after transaction costs is highest at 3.19\% and significant at the $1 \%$ level. In short, the PEAD strategies are still highly profitable after accounting for transaction costs, and the PEAD strategy that combines SUECF, SUE, and SUETAIL is the most profitable. 
Table A3. Average Market Capitalization, Turnover, and PEAD after Transaction

Costs for Portfolios Based on DSUECF, DSUE, and DSUETAIL

\begin{tabular}{|c|c|c|c|}
\hline & $\begin{array}{l}\text { Average Market Capitalization } \\
\text { (millions of dollars) }\end{array}$ & $\begin{array}{l}\text { Average } \\
\text { Turnover }\end{array}$ & $\begin{array}{l}\text { PEAD after Transaction } \\
\text { Costs }\end{array}$ \\
\hline \multicolumn{4}{|c|}{$\begin{array}{l}\text { A. Market capitalization, turnover, and PEAD after transaction costs for stocks from } 20 \% \text { bottom } \\
\text { (short) and } 20 \% \text { top (long) of both DSUECF and SUETAIL }\end{array}$} \\
\hline Short & 2,060 & 0.0126 & -0.0006 \\
\hline Long & 2,775 & 0.0133 & 0.0203 \\
\hline Hedge & & & $0.0209^{* *}$ \\
\hline$t$-Statistic & & & 3.30 \\
\hline \multicolumn{4}{|c|}{$\begin{array}{l}\text { B. Market capitalization, turnover, and PEAD after transaction costs for stocks from } 20 \% \text { bottom } \\
\text { (short) and } 20 \% \text { top (long) of both DSUE and SUETAIL }\end{array}$} \\
\hline Short & 2,432 & 0.0132 & 0.0003 \\
\hline Long & 2,762 & 0.0146 & 0.0208 \\
\hline Hedge & & & $0.0205^{*}$ \\
\hline$t$-Statistic & & & 2.54 \\
\hline \multicolumn{4}{|c|}{$\begin{array}{l}\text { C. Market capitalization, turnover, and PEAD after transaction costs for stocks from } 20 \% \text { bottom } \\
\text { (short) and } 20 \% \text { top (long) of SUECF, SUE, and SUETAIL simultaneously }\end{array}$} \\
\hline Short & 1,268 & 0.0142 & -0.0025 \\
\hline Long & 2,460 & 0.0152 & 0.0294 \\
\hline Hedge & & & $0.0319^{* *}$ \\
\hline$t$-Statistic & & & 2.86 \\
\hline
\end{tabular}

*Significant at the 5\% level.

**Significant at the $1 \%$ level.

\section{Other Untabled Robustness} Tests

We also report other untabled robustness test results regarding opposite signs between SUETAIL and SUECF, the staleness of the consensus forecast, the exclusion of extreme returns, SUETAIL and forecast dispersion, truncated tail forecasts, and annual performance.

\section{Opposite Signs between SUETAIL and SUECF}

As explained earlier, consensus forecast errors can have opposite signs from tail forecast errors. Out of our entire sample of 126,205 observations, we found 21,827 instances ( $17 \%$ of the entire sample) where SUECF is positive and SUETAIL is negative and 13,863 instances ( $11 \%$ of the entire sample) where SUECF is negative and SUETAIL is positive.

These cases emphasize the fact that SUETAIL does indeed capture unique information that differs from that captured by SUECF. To assess the validity of this statement, we ran the regression represented by the first model in Panel B of Table 3 and substituted a dummy variable for DSUETAIL, whereby the dummy takes on a value of 1 when SUECF and SUETAIL have opposite signs and 0 otherwise. As expected, we found the coefficient on that variable to be significantly negative.
Zhou and Shon (2013) showed that for a significant portion of the population, an earnings surprise based on the consensus forecast is met with market reaction in the opposite direction of the surprise. We show another dimension that can, at least partially, explain why stock price may drop/rise on a positive/negative earnings surprise based on consensus forecasts.

\section{Staleness of Consensus Forecast}

The consensus forecast may be stale because of several old forecasts in the distribution, which raises the question of whether information in the tails of the forecast distribution is incremental information or whether such information comes from more recent forecasts. To address this concern, we investigated whether tail forecasts provide incremental information relative to the most recent forecast. In doing so, we computed SUECF using the most recent forecast (instead of the median), and we redid our main analysis with SUETAIL as the interactive variable. We documented the significant interactive effects of SUETAIL on CAR and SUECF and on PEAD and SUECF. Hence, the incremental information from SUETAIL is not due to staleness in the consensus forecast.

\section{Exclusion of Extreme Returns}

We excluded observations in the most extreme positive and negative $0.5 \%$ of PEAD and CAR $(-1,1)$, and 
our inferences remain unchanged. In fact, $t$-statistics are somewhat higher because the independent variables are less noisy. In addition, we excluded 11,250 company-quarter observations with only two identical earnings forecasts in the 90-day period before the earnings announcement date, and our results remain robust.

\section{SUETAIL and Forecast Dispersion}

To show that our new measure of earnings news captures information different from that of earnings forecast dispersion, we substituted STD for SUE in Table 4. Holding SUETAIL constant, we found significant returns to a trading strategy that takes long (short) positions in stocks whose SUECF and STD are both in the top (bottom) quintile of their respective distribution. These quarterly returns are $3.5 \%, 2.3 \%$, and $2.1 \%$, respectively, when SUETAIL is in the bottom, middle, and top quintiles of its distribution. The hedge return jumps to $4.4 \%$ with a trading strategy that takes long (short) positions in stocks whose three variables are in their respective top (bottom) quintile.

\section{Truncated Tail Forecasts}

In another robustness test, we replaced tail forecasts with the 10th percentile and 90th percentile values from the latest forecast distribution. We required at least 10 latest forecasts for an earnings announcement, which substantially reduced the sample size to 19,490 qualifying observations. This smaller sample is potentially important for two reasons. First, a single tail forecast may be due to noise or luck. Substituting the forecast at the 10th or 90th percentile captures a more general phenomenon of $10 \%$ of the analysts having forecasts that are some distance removed from the consensus. As this distance increases, the quality of the consensus as a proxy for market expectations diminishes. Second, the smaller sample has practical implications from the perspective of large funds that confine their investment strategies to large-cap stocks followed by more sell-side analysts. Using the 10th and 90th percentile values to compute SUETAIL and replicating the main tests of our study, we found that the results are almost identical to the results for the full sample, with no inferences changed.

\section{Annual Performance}

We examined the profitability of trading strategies on an annual basis and found that trading strategies corresponding to the PEAD associated with priorquarter earnings surprises are consistently profitable year after year throughout our 26-year sample period. The hedge portfolios based on long (short) positions in the top (bottom) quintile of the SUE distribution produce positive excess returns in all years except 2001, 2008, and 2009. When the hedge portfolios combine information from SUETAIL by restricting the observations to those with SUETAIL also in the top (bottom) quintile of its distribution, trading profits increase in every year. We found similar evidence with respect to combinations of SUECF and SUETAIL and with respect to combinations of all three variables: SUE, SUECF, and SUETAIL.

\section{Notes}

1. Media reports of companies' quarterly earnings generally include GAAP and non-GAAP measures of actual earnings for both the current quarter and the same quarter of the previous year, along with a consensus of analyst forecasts taken from a data aggregator, such as Thomson Reuters. Data aggregators maintain or contribute to freely and easily accessible websites with the high and low estimates in the distribution of forecasts from which the consensus emerges (e.g., Reuters, Yahoo! Finance). To the best of our knowledge, our study is the first to rigorously analyze the information content of quarterly earnings forecasts in the tails of the distribution.

Note that we use the terms earnings news, earnings surprise, unexpected earnings, and forecast error interchangeably in this article.

2. In our study, we identified an approach that improves on the consensus forecast in judging the information content of earnings announcements. This approach is consistent with Beckers, Steliaros, and Thomson (2004), who found that active portfolio managers and especially buy-side analysts seek to improve on consensus forecasts in identifying investment opportunities.

3. Consistent with prior literature, we defined earnings surprise (based on a rolling seasonal random walk) as the difference between actual earnings for the current fiscal quarter and actual earnings for the same fiscal quarter of the previous fiscal year.

4. Several studies have documented that transaction costs are the main impediment to arbitraging PEAD (see, e.g., Ng, Rusticus, and Verdi 2008; Chordia, Goyal, Sadka, Sadka, and Shivakumar 2009) and that information risk mutes the stock price response to earnings information (Yan and Zhao 2011), leading to a more pronounced PEAD. In our study, using the best estimate of transaction costs (Chung and Zhang 2014) and usual proxies for information risk, such as analyst forecast dispersion and stock return volatility (Zhang 2006), we documented that PEAD, especially PEAD based on multiple unexpected earnings proxies, is not fully explained by transaction costs or information risk. These findings are consistent with Battalio and Mendenhall (2011) and Yan and Zhao (2011), who documented that PEAD-based trading strategies are highly profitable after accounting for transaction costs and information risk.

5. Researchers analyzing minimum and maximum values have found many effective applications. In a capital market context, George and Hwang (2004) demonstrated the profitability of momentum trading strategies timed to buy (sell) stocks when they reach the new 52-week high (low) point. Although investors had already been using that information to inform their trading decisions, George and Hwang provided the first largesample scientific evidence of the importance of that widely available statistic. In a similar vein, our study provides the 
first large-sample scientific evidence of the importance of earnings news based on broadly available high- and low-earnings forecasts.

6. Although in our examples we ignored the scalar for brevity, in our empirical tests, we scaled all variables as described in Equation 1.

7. Zhou and Shon (2013) documented that more than $40 \%$ of earnings surprises are met by opposite-direction stock price reactions, suggesting that consensus forecasts are not necessarily good proxies for the "true" market expectations. Our example illustrates, at least partially, why the market may react in the opposite direction of a positive earnings surprise based on the consensus forecast, emphasizing the need to go beyond the usual assumption of consensus forecasts as the best proxies for market expectations.

8. Our results are not unduly influenced by any particular industry. The sample includes 16 SIC code-defined industries, with the smallest (largest) representation from agriculture (financial services) at $0.17 \%$ (17.78\%). More importantly, no single industry is unevenly split between the top and bottom deciles of SUECF or SUETAIL. For example, $17.46 \%$ (18.11\%) of the observations in the top (bottom) decile of the SUETAIL distribution are from the financial services industry.

9. For our assessment of the robustness of our main results to the inclusion of this and other control variables, see Appendix A.
10. Brandt et al. (2008) derived EAR in the same way that we derived CAR $(-1,1)$.

11. Another way to look at how the tail forecast informs a momentum trader is to consider what happens if the investor/analyst ignores the information in SUETAIL and takes long (short) positions in stocks with large (small) SUECF and small (large) SUETAIL. In that case, the hedge portfolio return is a statistically insignificant $0.83 \%-0.53 \%=0.3 \%$. Thus, large positive (or negative) consensus forecast errors do not justify a trading strategy that ignores the information in the tail of the distribution from which the consensus emerges.

12. Holding SUETAIL constant and consistent with Brandt et al. (2008), we found significant returns to a trading strategy that takes long (short) positions in stocks whose SUECF and EAR are both in the top (bottom) quintile of their respective distribution. These quarterly returns are $1.7 \%, 3.1 \%$, and $3.4 \%$, respectively, when SUETAIL is in the bottom, middle, and top quintiles of its distribution-or $2.7 \%$, on average. The hedge return jumps to $5.4 \%$ with a trading strategy that takes long (short) positions in stocks whose three earnings surprise measures are in their respective top (bottom) quintile.

13. In an alternative specification, we added control variables used in Mendenhall's (2004) PEAD determinant model. Specifically, our results are robust to controls for the percentage of institutional ownership and the number of analyst forecasts.

\section{References}

Abarbanell, J., and V. Bernard. 1992. "Test of Analysts' Overreaction/Underreaction to Earnings Information as an Explanation for Anomalous Stock Price Behavior." Journal of Finance, vol. 47, no. 3 (July): 1181-1207.

Affleck-Graves, J., and R.R. Mendenhall. 1992. "The Relation between the Value Line Enigma and Post-Earnings-Announcement Drift." Journal of Financial Economics, vol. 31, no. 1: 75-96.

Bartov, E., D. Givoly, and C. Hayn. 2002. “The Rewards to Meeting or Beating Earnings Expectations." Journal of Accounting and Economics, vol. 33, no. 2 (June): 173-204.

Bartov, E., S. Radhakrishnan, and I. Krinsky. 2000. “Investor Sophistication and Patterns in Stock Returns after Earnings Announcements." Accounting Review, vol. 75, no. 1 (January): 43-63.

Battalio, R.H., and R.R. Mendenhall. 2011. "Post-Earnings Announcement Drift: Bounds on Profitability for the Marginal Investor." Financial Review, vol. 46, no. 4 (November): 513-539.

Beckers, S., M. Steliaros, and A. Thomson. 2004. "Bias in European Analysts' Earnings Forecasts." Financial Analysts Journal, vol. 60, no. 2 (March/April): 74-85.

Berkman, H., and C. Truong. 2009. "Event Day 0? After Hours Earnings Announcements." Journal of Accounting Research, vol. 47, no. 1 (March): 71-103.

Bernard, V.L., and J.K. Thomas. 1990. “Evidence That Stock Prices Do Not Fully Reflect the Implications of Current Earnings for Future Earnings." Journal of Accounting and Economics, vol. 13, no. 4 (December): 305-340.

Bhushan, R. 1994. "An Informational Efficiency Perspective on Post Earnings Announcement Drift." Journal of Accounting and Economics, vol. 18, no. 1 (July): 45-65.

Brandt, M.W., R. Kishore, P. Santa-Clara, and M. Venkatachalam. 2008. "Earnings Announcements Are Full of Surprises." Working paper, Duke University.
Cen, L., G. Hilary, and K.C.J. Wei. 2013. "The Role of Anchoring Bias in the Equity Market: Evidence from Analysts' Earnings Forecasts and Stock Returns." Journal of Financial and Quantitative Analysis, vol. 48, no. 1 (February): 47-76.

Chan, L.K.C., N. Jegadeesh, and J. Lakonishok. 1996. "Momentum Strategies." Journal of Finance, vol. 51, no. 5 (December): 1681-1713.

Chordia, T., A. Goyal, G. Sadka, R. Sadka, and L. Shivakumar. 2009. "Liquidity and the Post-Earnings-Announcement Drift." Financial Analysts Journal, vol. 65, no. 4 (July/August): 18-32.

Chordia, T., and L. Shivakumar. 2006. "Earnings and Price Momentum." Journal of Financial Economics, vol. 80, no. 3 (June): 627-656.

Chung, K.H., and H. Zhang. 2014. "A Simple Approximation of Intraday Spreads Using Daily Data." Journal of Financial Markets, vol. 17 (January): 94-120.

Collins, D.W., and P. Hribar. 2000. "Earnings-Based and Accrual-Based Market Anomalies: One Effect or Two?" Journal of Accounting and Economics, vol. 29, no. 1 (January): 101-123.

Dische, A. 2002. "Dispersion in Analyst Forecasts and the Profitability of Earnings Momentum Strategies." European Financial Management, vol. 8, no. 2 (June): 211-228.

Francis, J., R. LaFond, P. Olsson, and K. Schipper. 2004. “Costs of Equity and Earnings Attributes." Accounting Review, vol. 79, no. 4 (August): 967-1010.

Freeman, R.N., and S. Tse. 1989. "The Multiperiod Information Content of Accounting Earnings: Confirmations and Contradictions of Previous Earnings Reports." Journal of Accounting Research, vol. 27 (Supplement): 49-79.

Gar, I.D., G. Ormazabal, and D.J. Taylor. 2010. “Correcting for Cross-Sectional and Time-Series Dependence in Accounting Research." Accounting Review, vol. 85, no. 2 (March): 485-512.

Garfinkel, J., and J. Sokobin. 2006. "Volume, Opinion Divergence, and Returns: A Study of Post-Earnings Announcement Drift." Journal of Accounting Research, vol. 44, no. 1 (March): 85-112. 
George, T.J., and C. Hwang. 2004. "The 52-Week High and Momentum Investing." Journal of Finance, vol. 59, no. 5 (October): 2145-2176.

Jegadeesh, N., and J. Livnat. 2006. “Post-Earnings-Announcement Drift: The Role of Revenue Surprises." Financial Analysts Journal, vol. 62, no. 2 (March/April): 22-34.

Kasznik, R., and M. McNichols. 2002. “Does Meeting Earnings Expectations Matter? Evidence from Analyst Forecast Revisions and Share Prices." Journal of Accounting Research, vol. 40, no. 3 (June): 727-759.

Lerman, A., J. Livnat, and R.R. Mendenhall. 2007. “Double Surprise into Higher Future Returns." Financial Analysts Journal, vol. 63, no. 4 (July/August): 63-71.

Liang, L. 2003. "Post-Earnings Announcement Drift and Market Participants' Information Processing Biases." Review of Accounting Studies, vol. 8, no. 2 (June): 321-345.

Livnat, J., and R.R. Mendenhall. 2006. "Comparing the Post-Earnings Announcement Drift for Surprises Calculated from Analyst and Time Series Forecasts." Journal of Accounting Research, vol. 44, no. 1 (March): 177-205.

Mendenhall, R.R. 2004. "Arbitrage Risk and Post Earnings Announcement Drift." Journal of Business, vol. 77, no. 4 (October): 875-894.

Ng, J., T.O. Rusticus, and R.S. Verdi. 2008. "Implications of Transaction Costs for the Post-Earnings Announcement Drift." Journal of Accounting Research, vol. 46, no. 3 (June): 661-696.

Petersen, M.A. 2009. “Estimating Standard Errors in Finance Panel Data Sets: Comparing Approaches." Review of Financial Studies, vol. 22, no. 1 (January): 435-480.
Raedy, J., P. Shane, and S. Yang. 2006. "Horizon-Dependent Underreaction in Financial Analysts' Earnings Forecasts." Contemporary Accounting Research, vol. 23, no. 1 (Spring): 291-322.

Ramnath, S., S. Rock, and P. Shane. 2005. "Value Line and I/B/E/S Earnings Forecasts." International Journal of Forecasting, vol. 21, no. 1 (January-March): 185-198.

Shane, P., and P. Brous. 2001. "Investor and (Value Line) Analyst Underreaction to Information about Future Earnings: The Corrective Role of Earnings Surprise Information." Journal of Accounting Research, vol. 39, no. 2 (September): 387-404.

Thompson, S.B. 2011. "Simple Formulas for Standard Errors That Cluster by Both Firm and Time." Journal of Financial Economics, vol. 99, no. 1 (January): 1-10.

Yan, Z., and Y. Zhao. 2011. "When Two Anomalies Meet: The Post-Earnings Announcement Drift and the Value-Glamour Anomaly." Financial Analysts Journal, vol. 67, no. 6 (November/ December): 46-60.

Zhang, F. 2006. "Information Uncertainty and Stock Returns." Journal of Finance, vol. 61, no. 1 (February): 105-137.

Zhou, H., and J.Q. Zhu. 2012. "Jump on the Post-Earnings Announcement Drift." Financial Analysts Journal, vol. 68, no. 3 (May/June): 63-80.

Zhou, P., and J. Shon. 2013. Option Strategies for Earnings Announcements: A Comprehensive, Empirical Analysis. Upper Saddle River, NJ: Pearson Education.

\section{LET'S ALL LEARN HOW TO FISH... TO SUSTAIN LONG-TERM ECONOMIC GROWTH}

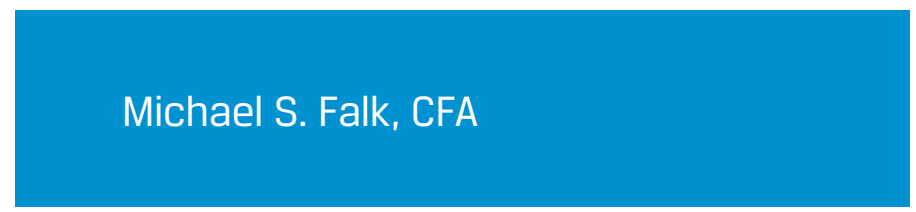

Have we taught too few individuals how to fish for themselves and handed out too many fish?

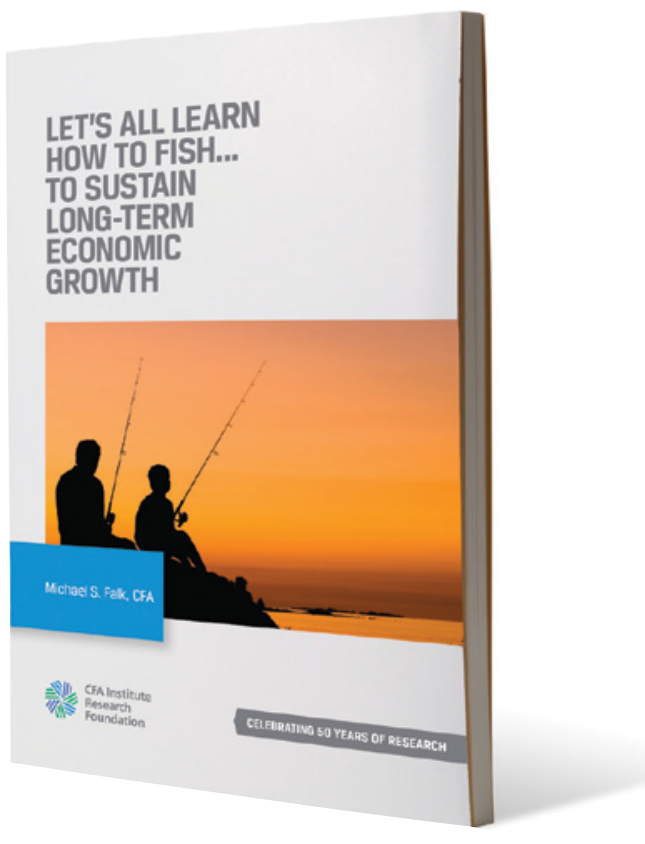

For more information or to download a free copy, visit www.cfainstitute.org. 